\title{
Student Experience Conducting Transactions Buy and Sell Salam (orders) On-Line
}

\author{
Azulaidin \\ Economy Faculty, Amir Hamzah University, Medan, Indonesia \\ Eliakim_purba@yahoo.com
}

\begin{abstract}
The aim of this paper to give solution to muslim in buying-sell product On-Line to avoid Gharar and Riba in Muamalah system. There are two kinds of buying and selling in practice, namely buying and selling directly and buying and selling indirectly. Direct buying and selling, for example: buying and selling in traditional markets and minimarkets / supermarkets where the buyer can check or choose the item to be bought directly. While, indirect buying and selling can be done by buying and selling Salam (orders). To collecting the data, the researcher uses interviews method.
\end{abstract}

Keyword : business; economy; profit; salam

\section{Introduction}

In Muamalah system, there are several forms of trading transactions known as Islam. One of them is a sale or purchase transaction. There are two kinds of buying and selling in practice, namely buying and selling directly and buying and selling indirectly. Direct buying and selling, for example: buying and selling in traditional markets and minimarkets / supermarkets where the buyer can check or choose the item to be bought directly. While, indirect buying and selling can be done by buying and selling Salam (orders). Today, buying and selling can not only be done in markets and minimarkets. Buyers can trade and sell at any time, for example, buying and selling orders on-line, where buyers can directly choose the items needed in the form of orders, but the goods traded are only shown in the form of images that are equipped with prices and specifications of the item. Buying and selling orders in Islamic jurisprudence is called "bay 'as-salam", which is an agreement that the delivery of goods is postponed, or sells an item with the characteristics, criteria, types, characteristics that are clear by paying the price / capital earlier, while the goods are delivered later. As with buying and selling, the contract of buying and selling greetings must be fulfilled in harmony and the conditions. Salam is also called "as-salaf" (introduction), which is the sale of something with certain criteria that is still in dependence with immediate payment / immediate payment of capital / price.

In the modern era, buying and selling orders or greetings were more visible in the furniture, clothes, bags, shoes, cosmetics and others. Buying and selling orders can be done provided that the price of the item is paid in advance and the goods are sent in the future. The presence of buying and selling orders online has a side of advantages and disadvantages. The advantage is that transactions are more efficiently. Information will be more easily disseminated, and can open up greater opportunities to get sales profits different from other sellers who do not use the on-line system. The disadvantage is having the possibility of uncertain product quality risk, the occurrence of missed communication between the seller and the buyer, there is an element of Gharar, namely the element of uncertainty over the goods being traded because the item is not physically visible, and cannot be touched directly by the person order / buyer, and can allow losses to one party. The current phenomenon is buying and selling orders on-line, often we encounter many buyers who feel disappointed after seeing the goods ordered do not match what they ordered and do not match what they choose through images, for example the quality or size of clothing . 
So from that the principle of buying and selling must be applied in Islam, which must not harm one, avoid Gharar and Riba. In the implementation of buying and selling greetings (orders) on-line is legal if it can be realized harmoniously and the terms of buying and selling greetings (orders) must be fulfilled, so that buying and selling orders on-line can be done correctly, honestly and fairly.

\section{Literature Review}

\subsection{Definition of Buying and selling Salam (orders)}

In terms of greetings is buying and selling something with certain characteristics that will be delivered at a certain time. Buying and selling greetings is an object that is mentioned in its dependency or gives money in front in cash, the goods are delivered later for the specified time.

Sale and purchase of greetings is defined as a form of sale and purchase with upfront payments and delivery of goods at a later date with prices, specifications, characteristics, characteristics, type, quantity, residence and place of delivery of goods clearly, and agreed in advance in the contract.

From several explanations regarding the sale and purchase of greetings, the things that can cancel or expire the sale and purchase agreement, are:

a) Goods ordered do not exist at the specified time.

b) Goods sent are defective or not according to the agreement in the contract.

c) Goods sent are of lower quality, and buyers choose to reject or cancel the contract. Namely, if the goods sent do not match their quality and the buyer chooses to cancel the contract, then the buyer has the right to return the greeting capital. Cancellation is possible for the entire ordered item, which results in the return of all paid-in capital. You can also cancel part of the delivery of ordered goods with a partial return of capital.

d) Goods sent quality do not match the contract, but the buyer accepts it.

e) Goods ordered have been received by the buyer.

\subsection{Consumer Good}

a. A good or final good is any commodity that is produced by the consumers to satisfy current wants or needs. Consumer goods are ultimately consumed, rather than used in the production of another good. For example, a microwave oven that is sold to a consumer is a good or good consumer goods intermediate goods. For example, transistors can be used to make some further goods.

b. The term "final goods" includes only new goods. For instance, the GDP includes items counted from year to prevent double counting from production that is based on resales of the same item. In that context, the economic definition of goods includes commonly known as services.

c. Manufactured goods that have been processed in any way. As such, they are the opposite of raw materials, but they include intermediate goods as well as final goods.

Final goods can be classified into the following categories:

1. Durable goods

2. Non-durable goods

3. Services 
Consumer durable goods have a significant lifespan, which tends to be at least one year, based on the guarantee or warranty period. The maximum life depends on the durability of the product or good. On the other hand, capital goods, which are tangible in nature, such as machinery or building equipment that can be used in manufacturing of final products, are durable goods with limited production costs. The longevity and the often-higher cost are often to postpone expenditures on them. It will make the durable most volatile (or cost-dependent) component of consumption.

Consumer nondurable goods are purchased for immediate use or for use very soon. Generally, the lifespan of non-durable goods is a few minutes to up to three years: food, beverages, clothing, shoes and gasoline are examples.

Consumer services are the intangible in nature. They cannot be seen, felt or tasted by consumers but still give satisfaction to the consumer. They are also inseparable and variable in nature: they are thus simultaneously produced and consumed. Examples are haircuts, auto repairs and landscaping.

\subsection{Business}

Business is the activity of making one's living or making money by producing or

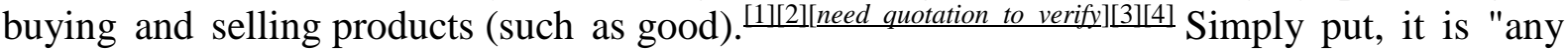
activity or enterprise entered into for profit. It does not mean it is a company, a corporation, partnership, or have any such formal organization, but it can range from a street peddler to General Motors."[5]

Having a business name does not separate the business entity from the owner, which means that the owner of the business is responsible and liable for debts incurred by the business. If the business acquires debts, the creditors can go after the owner's personal possessions. A business structure does not allow for corporate tax rates. The proprietor is personally taxed on all income from the business.

The term is also often used colloquially (but not by lawyers or by public officials) to refer to a company. A company, on the other hand, is a separate legal entity and provides for limited liability, as well as corporate tax rates. A company structure is more complicated and expensive to set up, but offers more protection and benefits for the owner.

Forms of business ownership vary by jurisdiction, but several common entities exist:

- Sole proprietorship: A sole proprietorship, also known as a sole trader, is owned by one person and operates for their benefit. The owner operates the business alone and may hire employees. A sole proprietor has unlimited liability for all obligations incurred by the business, whether from operating costs or judgments against the business. All assets of the business belong to a sole proprietor, including, for example, computer infrastructure, any inventory, manufacturing equipment, or retail fixtures, as well as any real property owned by the sole proprietor.

- Partnership: A partnership is a business owned by two or more people. In most forms of partnerships, each partner has unlimited liability for the debts incurred by the business. The three most prevalent types of for-profit partnerships are general partnerships, limited partnerships, and limited liability partnerships. ${ }^{[6]}$

- Corporation: The owners of a corporation have limited liability and the business has a separate legal personality from its owners. Corporations can be either governmentowned or privately owned, and they can organize either for profit or as nonprofit organizations. A privately owned, for-profit corporation is owned by its shareholders, 
who elect a board of directors to direct the corporation and hire its managerial staff. A privately owned, for-profit corporation can be either privately held by a small group of individuals, or publicly held, with publicly traded shares listed on a stock exchange.

- Cooperative: Often referred to as a "co-op", a cooperative is a limited-liability business that can organize as for-profit or not-for-profit. A cooperative differs from a corporation in that it has members, not shareholders, and they share decision-making authority. Cooperatives are typically classified as either consumer cooperatives or worker cooperatives. Cooperatives are fundamental to the ideology of economic democracy.

- Limited liability companies (LLC), limited liability partnerships, and other specific types of business organization protect their owners or shareholders from business failure by doing business under a separate legal entity with certain legal protections. In contrast, unincorporated businesses or persons working on their own are usually not as protected. ${ }^{[7][8]}$

- Franchises: A franchise is a system in which entrepreneurs purchase the rights to open and run a business from a larger corporation. ${ }^{[9]}$ Franchising in the United States is widespread and is a major economic powerhouse. One out of twelve retail businesses in the United States are franchised and 8 million people are employed in a franchised business. ${ }^{[10]}$

- A company limited by guarantee: Commonly used where companies are formed for noncommercial purposes, such as clubs or charities. The members guarantee the payment of certain (usually nominal) amounts if the company goes into insolvent liquidation, but otherwise, they have no economic rights in relation to the company. This type of company is common in England. A company limited by guarantee may be with or without having share capital.

- A company limited by shares: The most common form of the company used for business ventures. Specifically, a limited company is a "company in which the liability of each shareholder is limited to the amount individually invested" with corporations being "the most common example of a limited company."[11] This type of company is common in England and many English-speaking countries. A company limited by shares may be a

- publicly traded company or a

- privately held company

- A company limited by guarantee with a share capital: A hybrid entity, usually used where the company is formed for noncommercial purposes, but the activities of the company are partly funded by investors who expect a return. This type of company may no longer be formed in the UK, although provisions still exist in law for them to exist. ${ }^{[12]}$

- A limited liability company: "A company—statutorily authorized in certain states that is characterized by limited liability, management by members or managers, and limitations on ownership transfer", i.e., L.L.C. ${ }^{[1]}$ LLC structure has been called "hybrid" in that it "combines the characteristics of a corporation and of a partnership or sole proprietorship". Like a corporation, it has limited liability for members of the company, and like a partnership it has "flow-through taxation to the members" and must be "dissolved upon the death or bankruptcy of a member". ${ }^{[13]}$

- An unlimited company with or without a share capital: A hybrid entity, a company where the liability of members or shareholders for the debts (if any) of the company are not limited. In this case doctrine of a veil of incorporation does not apply. 


\section{Less common types of companies are:}

- Companies formed by letters patent: Most corporations by letters patent are corporations sole and not companies as the term is commonly understood today.

- Charter corporations: Before the passing of modern company legislation, these were the only types of companies. Now they are relatively rare, except for very old companies that still survive (of which there are still many, particularly many British banks), or modern societies that fulfill a quasi-regulatory function (for example, the Bank of England is a corporation formed by a modern charter).

- Statutory companies: Relatively rare today, certain companies have been formed by a private statute passed in the relevant jurisdiction.

Note that "Ltd after the company's name signifies limited company, and PLC (public limited company) indicates that its shares are widely held." ${ }^{[14]}$

In legal parlance, the owners of a company are normally referred to as the "members". In a company limited or unlimited by shares (formed or incorporated with a share capital), this will be the shareholders. In a company limited by guarantee, this will be the guarantors. Some offshore jurisdictions have created special forms of offshore company in a bid to attract business for their jurisdictions. Examples include "segregated portfolio companies" and restricted purpose companies.

There are, however, many, many sub-categories of types of company that can be formed in various jurisdictions in the world. Companies are also sometimes distinguished into public companies and private companies for legal and regulatory purposes. Public companies are companies whose shares can be publicly traded, often (although not always) on a stock exchange which imposes listing requirements/Listing Rules as to the issued shares, the trading of shares and future issue of shares to help bolster the reputation of the exchange or particular market of an exchange. Private companies do not have publicly traded shares, and often contain restrictions on transfers of shares. In some jurisdictions, private companies have maximum numbers of shareholders.

A parent company is a company that owns enough voting stock in another firm to control management and operations by influencing or electing its board of directors; the second company being deemed as a subsidiary of the parent company. The definition of a parent company differs by jurisdiction, with the definition normally being defined by way of laws dealing with companies in that jurisdiction.

\section{Discussion}

The convenience offered by the sale and purchase of orders on-line has made many people, both women and men, like to buy and sell transactions on-line only by using electronic devices (communication) such as cellphones or laptops. Seeing the current phenomenon, where technology is increasingly sophisticated, the internet is easy to get and easy to use and cheap. Business people continue to aspire to see the opportunity by making a network or website to sell goods/ products or known as buying and selling orders online. Among the advances in information technology have helped a lot of trade is the internet. By utilizing the on-line network, business people (sellers) can offer or market as many goods / products as possible, and get unlimited consumers.

With the sale and purchase of online orders, it does not mean that the parties that make online transactions can be free to carry out business as they wish or there are no restrictions 
and rules in accordance with Shari'ah and provisions The law governing electronic transactions, namely the Republic of Indonesia Law Number 11 of 2008 concerning Electronic Information and Transactions and Republic of Indonesia Law Number 8 of 1999 concerning Consumer Protection. The various restrictions that apply in Shari'ah and the Act must still be implemented, so that the sale and purchase of orders or commerce on-line is carried out in line with the provisions of Islamic Shari'ah.

Therefore, for those who buy and sell orders on-line, both as business actors and as consumers in buying and selling, they must be careful to carry out the online buy-and-sell transactions. For fear that transactions carried out are not in accordance with Shari'a taught by the Prophet Muhammad and with the rules governing electronic transactions and Islamic Sharia provisions.

The following are the experiences of business people buying and selling orders on-line and online buyers / consumers of goods / products, namely:

The research results of the author, with the method of collecting data through interviews, Rifkha R, Muamalah Department (as a UIN-SU Student and as a businessman buying and selling orders online), talked about buying and selling orders online that currently selling activities This purchase is increasingly prevalent, but, as we know that the system of buying and selling orders online, the problem he faces is regarding payment of goods. Because consumers who order goods to him pay the price of the goods when the goods are there, in this case he cannot get the capital to run his business, because the consumers give up capital at the end. ${ }^{1}$

According to Evi Novita Sari, the Department of Islamic Counseling Guidance, talking about buying and selling orders online is getting better and more diverse. As, we know that buying and selling orders online can make it easier for us to order goods without having to go to the store. And we can see in the form of pictures and explanations about the items offered / promoted. He once ordered a bag, and after the item arrived and received, the item matched the color and size seen from the picture. He said, as consumers, buying and selling orders online at this time is very helpful for the community to meet the needs that they want because there are advantages and benefits, and we can avoid fraud and obscurity of goods by finding information about the goods ordered.

According to Dian Fitriani, Department of Social Sciences, that she is a business actor in buying and selling orders online, saying that with the help of the internet in running her business, she gets more profit in running her business, because of assistance from the internet through communication in the media social. He can disseminate information through the site, Young Women's Business, Facebook, Whats app and Massager. In this case, he as a business actor can save in terms of time and costs, because he offers his products through social media. Therefore, these products are known and ordered from several regions.

According to Nia Dwiana Rista, the Department of Arabic Language Education, regarding buying and selling orders online makes it easier for us to order goods without having to go to the intended store. However, in the online purchase of goods there are unsafe transactions and not yet Syar'i, because not all sites and websites are safe to access. He has opened a site that when the owner of the site was not his own but a shared room. Therefore, as a buyer we must be able to choose a site or website that is clearly owner and safe and Syar'i.

\footnotetext{
${ }^{1}$ Rifkha R, Mahasiswa, Muamalah Department-B in $9^{\text {th }}$ semester, as the owner of business selling-buying orders in On-Line System, the result of interview of Muamalah Department in UIN-SU Medan, August 2 ${ }^{\text {nd }}, 2018$.
} 
According to Ms. Desy, an employee at the UIN-SU Cooperative Unit, buying and selling orders on-line has a good impact and makes it easier for us to deliver the goods ordered even though the distance is far away, but with social media we can order products through social media. Therefore, trading on-line orders can be carried out in accordance with Islamic Shari'a and the rules governing it with the condition that business actors and buyers must be on the basis of honesty, good intentions, agreement and willingness to conduct transactions. In order for the transaction to be executed it is not canceled, which can cause a dispute between the parties.

From the research based on interviews with those who conducted the transaction, it can be concluded that the buying and selling of orders on-line is considered by the community to make it easier for us to fulfill the needs we want, even though not all online buy-and-sell transactions today with buying and selling greetings according to Islamic Shari'a and regulations regarding electronic transactions. However, basically buying and selling orders on-line has fulfilled the existence of a harmonious concept and the terms of buying and selling greetings according to Syafi'iyah scholars. This can be seen from the results of the research that harmony and the terms of the sale and purchase of greetings have been fulfilled, although not clearly and clearly implemented in the present, it is because of technological updates in accordance with the development of an increasingly advanced and modern era.

\section{Conclusion}

On-line buying and selling in the UIN-SU environment, especially among UIN-SU Medan students from several faculties that there are several transactions that fulfill the concept of buying and selling Salam. The sale and purchase of orders online at the UIN-SU students studied and interviewed by the author contained six online greetings and purchases transactions, of which there were five implementations of online on-line orders accordingly. Using the concept of buying and selling Salam according to Syafi'iyah appropriate with Islamic Shari'a and there is one implementation of buying and selling Salam on-line that has not appropriated with the concepts of Syafi'iyah and Islamic Shari'a.

Al Qur'an

\section{References}

Achmad Sunarto, Tarjamah Shahih Bukhari, Vol. III, Semarang: CV. Asy-Syifa', 1993

Abu Umar Basyir, Fikih Ekonomi Islam, (Jakarta: Darul Haq, 2015)

Abdurrahman Al-Jaziri, Al-Fiqh 'ala al-Mazahib al- 'Arba'ah, Juz II, (Beirut: Dar al-fikr, 1994)

Departemen Agama RI, Al-Quran dan Terjemahanya Al-Jumanatul 'Ali, (Jakarta:CV.J-Art, 2004)

Mardani, Fiqh Ekonomi Syariah :Fiqh Muamalah, (Jakarta: Kencana MediaGroup, 2012),

Mustafa Diib Al-Bugha, Fikih Islam Lengkap Penjelasan Hukum-hukum Islam Mazhab Syafi'i, Oleh Ahli Bahasa: D.A. Pkihsati, dkk, (Solo: Media Zikir, 2009)

Muhammad Syarbini Al-Khathib, Al-Iqna' Fi Hilli Alfaz Abi Syuja', Juz 2, (Mesir: AlMathba'ah Al- Azhariyah 1929 M/1347

Muhammad Abid As-Sindi, Musnad Syafi'i, (Bandung: Sinar Baru Algesindo, 2000

Nasrun Haroen, Figh Muamalah, (Jakarta: Gaya Media Pratama, 2007

Wahbah Az-Zuhaili, Fikih Islam Wa Adillatuhu, Vol.V; Translated by: Abdul Hayyie Al-

Kattani, at all, (Printed. I; Jakarta: Gema Insani, 2011 